\title{
Claude Lévi-Strauss (1908-2009)
}

The apotheosis of heroic anthropology

\section{Albert Doja}

Albert Doja is an Honorary Research Fellow at the Department of Anthropology University College London, and Professor of Sociology and Anthropology at the European University, Tirana. He gained his PhD in social anthropology from the École des Hautes Études en Sciences Sociales in Paris in 1993 and is a former research fellow of the Laboratoire d'Anthropologie Sociale founded by Claude LéviStrauss. He has held several academic positions in France, Britain, Ireland and Albania and in 2008 was elected to the Albanian Academy of Sciences. His email is a.doja@ucl.ac.uk.
Fig. 1 (right). Claude LéviStrauss in the Laboratoire d'Anthropologie Sociale, which he founded in Paris in 1960.

Fig. 2 (below). The young Lévi-Strauss as fieldworker and adventurer.

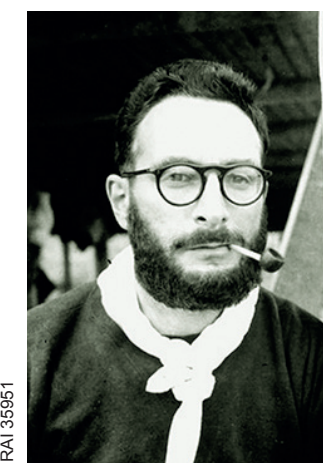

1. E.g. Henaff 2008, Sperber 2008, Hauschild 2008, Carneiro da Cunha 2008, Doja 2008a.

2. E.g. Bloch 2009, Sahlins 2010, Terray 2010, Maniglier 2010

Asch, M. 2005. Lévi-Strauss and the political: The elementary structures of kinship and the resolution of relations between indigenous peoples and settler states. Journal of the Royal Anthropological Institute 11(3): 425-444.
Claude Lévi-Strauss died on 30 October 2009. He lived to be a hundred years old and is widely recognized as 'the father of modern anthropology'. Here, Albert Doja assesses his influence on the discipline and beyond. [Ed.]

The centrality of Claude Lévi-Strauss in the evolution of 20th-century thought shows how he marked the very meaning of the last century and what he might have promised for 21 st-century anthropology. Centenary celebrations ${ }^{1}$ and obituaries ${ }^{2}$ appeared in a number of places, as many anthropologists have written and will continue to write about his life, works, legacy, and his immense contributions to anthropology. His corpus of work is far-reaching and comprehensive in scope, encompassing methodology, philosophy, history, humanism, mythology, linguistics, aesthetics, cognition and reasoning. However, his work is often misunderstood and his continuing relevance for contemporary theory must be acknowledged and accounted for. This is in my view the best way to commemorate his legacy to anthropology.

Anthropology today concerns itself with questions of migration, disease, famine, poverty, feminism, reflexivity, corruption, globalism, ethnic conflicts, civil wars, human rights, cultural activism, fundamentalism, terrorism, and many other related themes. An attempt to restore LéviStrauss to a central position can hardly prove immediately relevant to all of these social and political issues. Yet it is possible to show that structural anthropology may innovatively account for much more than the dynamics of social systems and the praxis of competitive and strategic practices.

\section{Structural anthropology}

The epistemological issues of anthropological knowledge and the ethical conception of the anthropologist's work are consistently present throughout Lévi-Strauss's work, in its ontological (nature of man and society), aetiological (denaturation of man and society) and salvational (return to the means, or the absence of means, to alleviate these evils) dimensions. Clearly, from the first volume of his Structural anthropology (1958), through his second collection (1973) and his 'view from afar' (1983) to his monumental Pléiade edition (2008), it is Lévi-Strauss's skill and talent to have been able to establish the theoretical foundations of a revolutionary contribution, both scientific and humanist, to general anthropology.

He first produced the high social theory of The elementary structures of kinship (1967 [1949]), describing the passage from nature to culture and revealing the foundations of human society. He then moved to the high science of Mythologiques (1964, 1966, 1968, 1971), explored the operation of the Savage mind (1962a), and revealed the foundations of human cognition. He produced innovative variations on his 'small mythologiques' $(1985,1991)$, on the Way of masks (1979), and exposed hidden aesthetics of the arts (1993), but he also produced the heroic quest of Tristes Tropiques (1955), precisely accounting for anthropology as both a science and a humanist discipline.

Indeed, Lévi-Strauss anticipated and called for what I believe must be the future of theoretical anthropology. Contrary to the received ideas of his critics, little of recent topical, ethical, methodological or epistemological interest escaped Lévi-Strauss's notice, understanding and engagement. Both at core and in the interstitial spaces of his writing

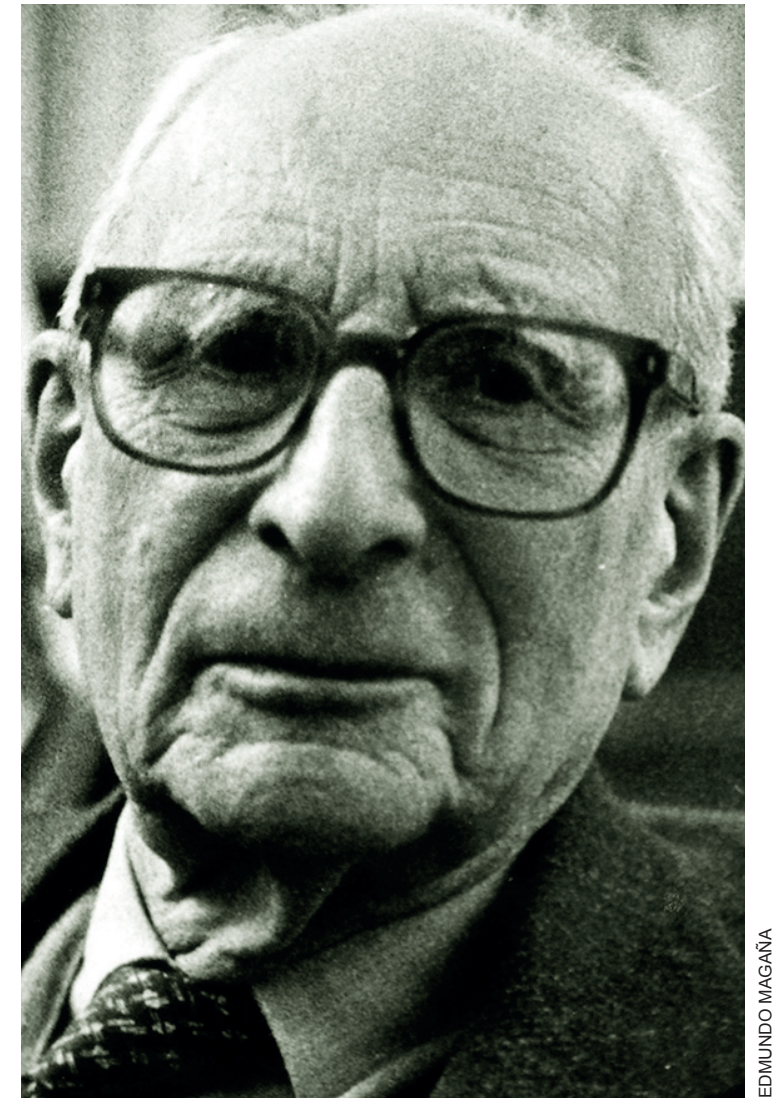

we can find the seeds of a new epistemology and a new ethics, involving a set of new assumptions and procedures for the acquisition of knowledge, a new approach to methodology and a new global awareness (see Doja 2005, 2006a, 2006c, 2008a).

However, particularly in the English-speaking world, the true value of Lévi-Strauss's works has been obscured by a number of misunderstandings, no doubt exacerbated by problems of cultural more than linguistic translation, as well as by the vagaries of intellectual fashion. Not only Lévi-Strauss's original approach to history, but above all his actual theoretical and epistemological contribution to general knowledge and the humanism of structural anthropology as a human science, appear neglected and rarely appreciated, if not deliberately misconstrued, despite the fact that they are essential aspects of his theory.

Some of these aspects could lay strong claim to having mapped, within anthropology, the philosophical parameters of an increasing concern with issues of political import in the post-colonial era, as well as with issues of contextualization and reflexivity in the face of the declining coherence of meta-narrative and grand theory. Within the context of the new form of humanism initiated by structural anthropology (see Doja 2008b), Lévi-Strauss used structural arguments coherently and correctly to analyse the cultural order and at the same time recognized the transient character of this order in terms of entropy, irreversibility and, not surprisingly, deconstruction and self-reflexivity. Arguably, some of these and other aspects of Lévi-Strauss's theory may be advanced as a workable methodology helping us to build innovative anthropological approaches to history, agency, culture and society.

His critics have insisted on addressing his substantive views, especially the inadequacy of his definition of struc- 
Armand, L. 2008. Language and the cybernetic mind. Theory, Culture \& Society, 25 (2): 127-152.

Bloch, M. 2009. Claude Lévi-Strauss obituary. The Guardian (4 November 2009):38.

Butler, J. 2004. Undoing gender. London/NewYork: Routledge.

Carneiro da Cunha, M. 2008. Lévi-Strauss aujourd'hui. Journal de la Société des Américanistes, 94(2):39-54.

Castaneda, Q.E. 2006.

Ethnography in the forest: An analysis of ethics in the morals of anthropology. Cultural Anthropology, 21(1):121-145

Carsten, J. and Hugh-Jones, S (eds) 1995. About the house: Lévi-Strauss and beyond. Cambridge: Cambridge University Press.

Charbonnier, G. (ed.) 1961. Entretiens avec Claude LéviStrauss. Paris: Plon.

Connor, S. 2010. Thinking things. Textual Practice, 24(1):1-20.

Constable, N. 2009. The commodification of intimacy: Marriage, sex, and reproductive labor. Annual Review of Anthropology 38(1):49-64.

Desveaux, E. 2001 Quadratura Americana: Essai d'anthropologie lévistraussienne. Genève: Georg Editeur.

Doja, A. 2005. The advent of heroic anthropology in the history of ideas, Journal of the History of Ideas 66(4): 633-650.

- 2006a. The shoulders of our giants: Claude Lévi-Strauss and his legacy in current anthropology. Social Science Information 45(1): 79-107.

-2006b. The kind of writing: Anthropology and the

rhetorical reproduction of post-modernism. Critique of Anthropology 26(2): 157-180.

-2006c. The predicament of heroic anthropology, Anthropology Today 22(3): 18-22.

-2007. Creative misreading and bricolage writing: A structural appraisal of a poststructuralist debate. Portuguese Review of the History of the Book 11(22): 89-104.

- 2008a. Claude Lévi-Strauss at his centennial: Toward a future anthropology. Theory Culture and Society 25(7-8): 321-340.

-2008b. From Neolithic naturalness to Tristes Tropiques: The emergence of Lévi-Strauss's new humanism. Theory, Culture and Society 25(1): 77-100.

-2008c. Instrumental border of gender and religious conversions in the Balkans. Religion, State and Society 36(1): 55-63.

- 2009. 'Morphodynamics and agency: From poststructuralism to neostructuralism'. Paper presented to the invite ture, history and agency and above all his brand of structuralism. These are undoubtedly key issues in understanding Lévi-Strauss's thought, and the rise of structuralism is historically inseparable from the increased prestige of anthropology. However, to equate Lévi-Strauss with structuralism is to distort our understanding of his legacy and his continuing relevance in anthropology and social theory. Indeed, while revisiting the old debate between Derrida and LéviStrauss on the place of writing (Doja 2006b, 2006c, 2007), I came to the same conclusion as many other authors - that we must legitimately ask to what extent, in the popular imagination at least, a version of structuralism invented retrospectively by 'post-structuralists' has been substituted for the real thing (cf. Wiseman 2009). Arguably, Lévi-Strauss's brand of structuralism extrapolated brilliantly from a particular moment of linguistics, demonstrating the wider implications of its findings for thinking about human culture, but in the structural analysis of myth more important influences can be suggested, beyond linguistic structuralism.

Lévi-Strauss developed anthropology into a scientific project with a more sophisticated intellectual purchase for understanding humanity than is generally acknowledged or than the discipline had previously, and has since, achieved. His theoretical interpretations brought about an epistemological break with previous methods of analysis, to the extent that we can refer to a real anthropological scientific revolution, at least with regard to the successive Copernican revolutions to which he subjected kinship and marriage, thinking as a classifying exercise, and the transformational logic of myths.

Lévi-Strauss's generalizations can provide easy targets for hostile critics, and there are flaws in some of his arguments, like the 'antipathy' towards Islam that he notoriously displayed in Tristes Tropiques, his reservations regarding the events of May '68 in France, or his campaign against the election of the first woman to the Académie Française. But while it is easy to show that he is sometimes wrong on points of detail, this does not detract from the validity of his major generalizations. Whatever the future impact of his work, and even if time may reveal problems and limitations of structural analysis, the fundamental method of LéviStrauss's theory, though less influential now than it was in the 1960 s, remains a massive intellectual achievement that has not been surpassed, and an innovation from which there can be no retreat.

Lévi-Strauss's structural hypotheses have had an unquestionable impact, even if they did not always seem wellgrounded or fertile. Structural analyses and procedures constitute an original set of theoretical reflections on cultural and social aspects of human life, and rest on assumptions that are neither tautological nor trivial, but relate to the very nature of human facts. Since at least the early 1950 s his peculiar 'view from afar' has also interrogated contemporary issues such as the place of traditional Christmas celebrations in modern society (1952b). He always offered unusual reflections on contemporary themes such as female sexuality (1998), the human condition and the productivity of the market economy (2001a), the avuncular relation between Earl Spencer and the sons of Princess Diana, mad cow disease and modern human sociality (2001b, 2004), or the similarities between mythological models and the interpretative quandaries of modern physics. Above all, it is not sufficiently understood that Lévi-Strauss was a profoundly ecological thinker. His critique of a 'corrupt' humanism that places 'man' above other living beings is today more relevant than ever. Not surprisingly, he repeatedly and uncompromisingly returned to it again and again (2007).

The works of Lévi-Straus cannot be reduced to the exposition of a method or doctrine. They constitute a complex assemblage of texts, often related by hidden connections, whose meaning in many ways remains to be discovered.
In the very different intellectual and political context of our time, what comes to the fore in rereading The savage mind, for example, is not so much the analysis of the logic of classificatory systems, but remarks on the place of affect in social relations, and the ethical dimension of Lévi-Strauss's thought. Arguably, his structural anthropology is, at its core, an epistemology that has already produced an original approach to ethics.

Despite his conceits and idiosyncracies, his rather cranky set of interests and obsessions, Lévi-Strauss has proved to be an enduring figure in the history of social theory and anthropology. With his acknowledgement that mental satisfaction is a product of things 'good to think' (1962b: 132), he moved anthropology toward a more formal method and more scientific aspirations. He inadvertently ignited an intellectual enthusiasm that swept through nearly all social sciences and the humanities and made of him, in Susan Sontag's terms, the first anthropologist to become 'a hero of our time' (Sontag 1990 [1963]).

As Clifford Geertz suggests, no anthropologist has been more insistent than Lévi-Strauss on the fact that "the practice of his profession has consisted of a personal quest, driven by a personal vision, and directed toward a personal salvation' (Geertz 1973 [1967]: 346). In the form of the tradition of the mythological heroic quest, with the anthropologist as its hero, as Richard Shweder put it, Lévi-Strauss transformed an expedition to the pristine interiors of the Amazon into a vision quest, and turned anthropology into a spiritual mission to defend humankind against itself (Hayes and Hayes 1970).

To this extent, in the 'heroic' practice of Lévi-Strauss's anthropology, that is, in the 'psychological ordeal' of ethnographic fieldwork, not only does he constantly and agonisingly feel compelled to call into question the parameters of his own existence and assumptions through contact with the exotic Other, but he is forced to watch helplessly as indigenous cultures are irrevocably destroyed by the processes of modernization. It is specifically this stance more than anything else that offers critical new perspectives for the analysis of differences in the reasoning, values, problematizations, and focus of ethics and morals in the distinct domains of ethnographic fieldwork, ethnographic representation, the general field of anthropology, and in the historiography of anthropology (Castaneda 2006).

\section{Scientific epistemologies}

At Lévi-Strauss's instigation, the anthropological approach came to comprise three stages - ethnography, ethnology, anthropology - articulated through the dual relationship of methodology and subject of analysis, proceeding from case studies to the description of general laws. With this passage from the particular to the general, a process of synthesis formerly restricted to sociology, Lévi-Strauss established the legitimacy of a theoretical anthropology as distinct from and complementary to ethnography as theoretical physics is distinct from and complementary to experimental physics. In addition, in his attempt to overcome the conflict between individualism and holism, he showed that sociology, in its study of aggregates of individuals using 'statistical models', and anthropology, in its study of the coherence of social structures using 'mechanical models' (Lévi-Strauss 1958: 311-313), entertain the same type of relationship with each other as thermodynamics with quantum mechanics in modern physics, since the latter respectively study the collective behaviour and the internal structure of atoms and molecules.

Lévi-Strauss's early works do not merely construct the first step of a structural study of kinship. What is interesting about Elementary structures of kinship (1949) is that this contribution to an extremely specialized branch of anthropology is accompanied by a more general contribution to 

ronment (see LeRoux 2009).

The principles of structural anthropology might then appear formally similar to the principles of quantum physics that provide the key to atomic structures. Not surprisingly, therefore, we may think of Lévi-Strauss in social science having demonstrated the rigorous patterning of the transformational structure of myth just as Einstein, in natural science, demonstrated the pattern of the structural relativity of the universe. In that case, Lévi-Strauss conferred the same status of 'absolute objects' on mythic schemas (1964: 21, 1971: 33), as Einstein did on the universe.

'If I have seen farther, it is by standing on the shoulders of giants,' declared Isaac Newton in 1676, referring to his own work on optics. Unfortunately and to the collective detriment of social sciences and anthropology, we all too often tend to neglect the shoulders of our giants, not so much out of disloyalty as out of the sad vanity of the increasingly individualistic world in which we live.

Perhaps Lévi-Strauss was not quite the Einstein he believed anthropology was waiting for (1958: 180), nor the Mendeleyev-like cosmologist of social sciences he strove to be (1955: 203). Nevertheless, by charting a periodic table of disciplines in which anthropology finds its assigned place (1973: 350-351), by constructing, in the spirit of the new physics, his celebrated 'atom of kinship' (1958: 58), and by conferring on mythic schemas the status of 'absolute objects' (1964: 21, 1971: 33), that is, a structural form similar to molecular stability, which becomes intelligible by the operation of a 'canonical formula' (1958: 252-253), he inspired an awakening to the anthropological vocation and the feeling of taking part in a brilliant and captivating new intellectual adventure.

In spite of many years of harsh criticism based on a superficial reading of his work, there are many who recognize that the structural methods of Lévi-Strauss constitute 'the most significant contemporary innovation' in the social and behavioural sciences (Gardner 1981: xii), and that 'one hundred years from now Lévi-Strauss's research program will be seen as more right-headed than that of his strongest critics - the true mark of an important thinker' (Gardner 1985: 241-242). Already, experimental research has demonstrated how narrative references, for instance, seen as variants of numeric sets forming mathematically constructive algebraic groups, can be held to support Lévi-Strauss's claim of an algebraic structure to human mind and cognition as derived from his structural analysis of myths (Haskell 2008).

Building on Levi-Strauss's (and others') train of thought, it has further been proposed that the generating functions of the semiotic status of algebraic variables provide a philosophical language that can explore the openness of mathematical signs to reinterpretation, and bridge some of the barriers between the philosophy of mathematics and critical approaches to knowledge (Wagner 2009). Similarly, whereas neurobiological naturalism particularly challenges theoretical social science to account for socio-ontological questions of structural constitution, it has been argued that Lévi-Strauss's theory in and of itself requires an advance meeting with the natural sciences, to the extent that a naturalist position can actually be deduced from the general context of the empirical fields of research within structural anthropology (Kauppert 2008).

In addition, the basic circuits and scaffolding of semantic fractals in web architecture provide a 'representation theory' unifying distinct semantic models, which can be shown to correspond to the singularity theory in mathematics and to the semiotics of narrative and mythological structures as described by Lévi-Strauss (Marrais 2008). Ultimately, software modelling of a given myth issued from the oral literature of a given culture, and the simulation of the corresponding myth transformations as described by Lévi- 
structuralist movement. 2nd edition. Chicago: University of Chicago Press.

1985. The mind's new science: A history of the cognitive revolution. New York: Basic Books.

Geertz, C. 1973 [1967].

The cerebral savage:

On the work of Claude

Lévi-Strauss. In The

interpretation of cultures,

pp. 345-359. New York:

Basic Books.

Godelier, M. 2004

Métamorphoses de la parenté. Paris: Fayard.

Gonzalez-Ruibal, A. 2006.

House societies vs.

kinship-based societies

An archaeological case

from Iron Age Europe.

Journal of Anthropological

Archaeology, 25(1):144-

173

Hardenberg, R. 2007.

Das 'einschliessende

Haus': Wertehierarchien

und das Konzept der

'Hausgesellschaft' im

interkulturellen Vergleich.

Anthropos, 102(1):157-168

Haskell, R. 2008. Claude

Lévi-Strauss reconsidered:

Cognitive science,

epistemology, and the (not

so savage) algebraic mind.

Cognitive Semiotics, 3 :

65-90.

Hauschild, T. 2008. Der

alte Master: Claude

Lévi-Strauss zum 100.

Geburtstag. Saeculum,

59(2):169-176.

Hayes, N.E. and Hayes, T.

(eds) 1970. Claude Lévi-

Strauss: The anthropologist

as hero. Cambridge, MA:

MIT Press.

Henaff, M. 2008. Lévi-Strauss et le principe de réciprocité European Journal of Sociology 49(2):315-321.

Joyce, R. and Gillespie, S. 2000 Beyond kinship: Social and material reproduction in house societies. Philadelphia: University of Pennsylvania Press.

Kaldor, M. 1999. New and old wars: Organized violence in a global era. Stanford: Stanford University Press.

Kauppert, M. 2008. Ein romantisches Gehirn: Zum cerebral Turn der strukturalen Anthropologie. Berliner Journal für Soziologie, 18(2):307-333

Lafontaine, C. 2007. The cybernetic matrix of French theory. Theory, Culture \& Society, 24(5):27-46.

Leinaweaver, J. 2010. Losing Lévi-Strauss: The 2009 yea in cultural anthropology. American Anthropologist 112(2): 219-227.

LeRoux, Ronan. 2009. Lévi-Strauss, une réception paradoxale de la cybernétique. L'Homme, 1(189):165-190.

Leyton, C.A,. 2007. Intendierte Machtallianzen. LéviStrauss' Allianzbegriff und die Kritik 'künstlicher;

Verwandtschaft, Anthropos, 102(1):169-186

Lévi-Strauss, C. 1952a. Race et histoire. Paris: Unesco.
Strauss, show not only how right he was in his structura analysis of mythical thought, but also the potential benefits of deploying Lévi-Straussian structural analysis in computer science modelling and in simulation concepts and tools to be applied to social sciences and the humanities (Santucci, Gentili and Thury-Bouvet 2010).

\section{Social and political concerns}

It is in some ways remarkable that many of those widely circulated Lévi-Straussian ideas that nourished anthropology for so long, like kinship, taxonomy or transformational analysis, are still 'good to think' and continue to resonate as 'thinking things' (Connor 2010) for contemporary anthropologists. As others have pointed out, it is not too much of a stretch to apply the label of Lévi-Strauss's 'bricoleur' to much of cultural anthropology today. Many anthropologists use multi-sited, collaborative and otherwise innovative techniques - drawing on what is available, making tools where there were none before, and generally thinking creatively in methodological terms (Leinaweaver 2010). In particular, collaborative work is being forged, bricoleur-fashion, among scholars coming from different perspectives, trainings and backgrounds.

For Lévi-Strauss, as he developed the opposed idealtypes of the bricoleur and the engineer, bricolage involved an ideal-typical configuration of acting (practice), knowing (epistemology) and underlying world view (metaphysics). As various forms of collective bricolage are explored, depending on the type of interaction and the nature of the conventions employed, the bricoleur's legitimacy is now being recognized even in organization and management theory (Duymedjian and Rüling 2010) or in nursing research, education and practice (Warne and McAndrew 2009). Not only can bricolage-based arrangements be embedded in an organizational or nursing context as a way of understanding better the interrelated connections between theory, practice and felt experience, but we can also move beyond research methods as merely procedures to qualitative methodologies that respect the complexities of the lived world. More than anything else, Lévi-Strauss will be remembered for prompting many researchers to generate more imaginative hypotheses, which can then be tested through empirical research. But this in itself suggests that the impact of structural anthropology is not limited to the remarkable achievements that established its initial legitimacy.

Among many initiatives, we need to pay tribute to the project of some scholars to recuperate these procedures, without however merely implementing Lévi-Strauss's method, in applying the dynamic aspect of structuralism and its transformational perspective to other socio-cultural phenomena, like ritual to which Lévi-Strauss seemed refractory, or social organization, where his analysis is generally seen as tinged with functionalism (Desveaux 2001). In another departure, a reading of The elementary structures of kinship as a political treatise reinvigorates the analysis of Lévi-Strauss's oeuvre by focusing on the political implications of his intellectual project (Asch 2005)

This perspective effectively counters the narrow-minded analyses of the feminist critique (e.g. Butler 2004), which focus on his supposed misogynist objectification of women, his alleged homophobic valorization of heterosexual marriage against other forms of alliance, or his claimed essentialist reproduction of transmissible racial purity (see Strong 2002; Fassin 2009). Lévi-Strauss's theory provides conceptual tools to perceive, analyse and name the logics of how gender is a socially imposed division of the sexes, a product of the social relations of sexuality that transform males and females into social beings. What Lévi-Strauss called 'exchange of women' is a seductive and powerful concept in that from the start it places the oppression of women within social systems rather than in biology, while his view of the origins of society in the incest taboo leads to a fundamentally anti-liberal understanding of the inescapability of social relationships.

It is Lévi-Strauss's merit to have laid the ground for understanding the most important transformations of gender, the conversion of female labour into male wealth, the conversion of female lives into marriage alliances, the contribution of marriage to political power, and so on. It is at Lévi-Strauss's instigation, indeed, that traditional concerns of anthropology and social science have been reworked to include the implications of gender in the evolution of social stratification and the origin of the state. Obviously, LéviStrauss's classic intervention explored fundamental theoretical and analytical issues of vital interest to the study of society. He clearly demonstrated how gender and sexuality are deeply implicated in the study and practice of kinship, while he provided a unique, counter-hegemonic alternative to conventional narratives in Western political thought. Social exclusion and antagonism cannot be explained simply in terms of the assumption that society emerged out of a structurally unbreakable rule of heterogeneity (Lévi-Strauss described the incest taboo as rendering structurally impossible the closure of society through self-identity). However, it was through his interpretation of dual organizations that he accounted for both social exclusion and social antagonism on the basis of a social difference theory (Marchart 2008).

In addition, although vague on 'fictive' kinship forms other than affinal relations, Lévi-Strauss's alliance theory leads us out of the quandary into which Schneider's critique (1984) drew the anthropology of kinship. Lévi-Strauss's emphasis on the intended construction of kinship makes it possible to consider other forms of 'artificial kinship' as being conceptually central to alliance theory (Leyton 2007). In this case, not only are ritual and mimetic forms of kinship emancipated from the traditional anthropological treatment that triggered Schneider's critique, but any kinship form can be seen as an alliance practice resting on converged individual power interests and ultimately offering a significant perspective for critical social research.

Research on kinship became controversial in the 1970 s and 1980s following belated recognition of the biocentrism of Western assumptions underlying its central premises. Notwithstanding the vagaries of anthropological interest in the study of kinship, Lévi-Strauss's singular concept of 'house' and 'house societies', developed in his last lectures (1984), has been taken up very productively in later anthropological studies (Carsten and Hugh-Jones 1995, Joyce and Gillespie 2000). In recent years the debate about house societies has fostered a renewed interest in kinship studies and several examples of house societies have been proposed and thoroughly studied by historians, anthropologists and archaeologists (Gonzalez-Ruibal 2006). Arguably, a better understanding of the role of the house is gained when it is seen as an expression of the socio-cosmic whole and the hierarchical system of ideas and values attached to social relations in certain societies (Hardenberg 2007), or when the centrality of the house as an ideological form is assumed through the association between hosting and social worth, an association that may well be fundamental to house societies in general (Sissons 2010).

While the ideas he developed generally in his kinship studies continue to be addressed in some depth by the scholarly community (Godelier 2004), over the last two decades, research exploring how kinship is thought, enacted and made meaningful has become a priority among scholars focusing on new and old reproductive technologies and the intensification and complex interconnectivity of local and global processes as they relate to cross-border marriages, or migrant domestic and sex workers. These studies demonstrate growing scholarly interest in how social relations have become ever more geographically dispersed, impersonal, 
- 1952b. Le Père Noël supplicié. Toulouse: Sables 1994.

- 1955. Tristes tropiques. Paris: Plon.

-1958. Anthropologie structurale. Paris: Plon.

- 1962a. La pensée sauvage. Paris: Plon.

- 1962b. Le totémisme aujourd'hui. Paris: Presses Universitaires de France.

- 1964. Le cru et le cuit (Mythologiques I). Paris: Plon.

- 1966. Du miel aux cendres (Mythologiques II). Paris: Plon.

— 1967 [1949]. Les structures élémentaires de la parenté. 2nd edition. Paris/The Hague: Mouton

- 1968. L'origine des manières de table (Mythologiques III). Paris: Plon.

- 1971. L'homme nu (Mythologiques IV). Paris: Plon.

- 1973. Anthropologie structurale 2. Paris: Plon.

- 1979. La voie des masques. 2nd edition. Paris: Plon.

- 1983. Le regard éloigné. Paris: Plon.

- 1984. Paroles données. Paris: Plon.

- 1985. La potière jalouse. Paris: Plon.

- 1991. Histoire de lynx. Paris: Plon.

- 1993. Regarder, écouter, lire. Paris: Plon.

— 1998. La sexualité féminine et l'origine de la société. Les Temps Modernes, 53(598): 78-84

- 2001a. Productivité et condition humaine. Etudes Rurales 159-160: 129-144.

- 2001b. La leçon de sagesse des vaches folles. Études Rurales 157-158: 9-13.

- 2004. Nous sommes tous des cannibales. In: Izard, Michel (ed.), Claude LéviStrauss, p. 34-36. Paris: Cahiers de l'Herne.

-2007. Unesco at 60. Diogenes 54(3): 5-10.

2008. Oeuvres. Paris: Gallimard (Pléiade)

Maniglier, P. 2010. A LéviStraussian century: Claude Lévi-Strauss, 1908-2009. Radical Philosophy (160): 65-68.

Marchart, O. 2008.

Ungesellschaftliche Gesellschaftlichkeit: Exklusion und Antagonismus bei Lévi-Strauss, unter Berücksichtigung von Lacan, Laclau und Luhmann, Soziale Systeme, 14(2):370-396

Maranda, P. (ed.) 2001 The double twist: From ethnography to morphodynamics. Toronto: University of Toronto Press.

Marrais, R.P.C. de. 2008. Natural numbers, natural language: Architecting the Semantic Web. Paper presented to the Fourth International Conference on Natural Computation, vol. 3 , pp. 260-266. mediated by and implicated in broader political-economic or capitalist processes, as well as a deepening concern for how intimate and personal relations, especially those linked to reproductive labour, adoption, and domestic units, have become more explicitly commodified and linked in many cases to transnational mobility and migration, presenting new ethnographic challenges and opportunities (Constable 2009).

The fundamental question of these and other complex interconnections between intimate and broader political processes is certainly not purely rhetorical, for example whether it is 'house societies' or broader settings that employ the 'language of kinship' to talk about political and economic interests, as Lévi-Strauss claims, or whether in fact it is LéviStrauss who employs the 'language of kinship' to talk about relations which a variety of societies may phrase in the 'language of the house' or broader political processes.

The more important issue is that in such global systems and processes it is above all women who, skilfully manipulated, play the role of power levers in both ritualized and organized violence. Scholars have argued for decades about the relationship between biological sex and organized violence, but in recent years research has brought new understanding of the rapidity with which gendered roles and ideas about masculinity and femininity can change in times of war, and the role of militarization in constructing and enforcing the meaning of manhood and womanhood (see also Doja 2008c). Especially in the post-Cold War period, 'new wars' (Kaldor 1999) have mobilized gender in multiple ways, and peace-building is often managed by external humanitarian organizations that inadvertently essentialize ideas of men as perpetrators of violence and women as victims (Moran 2010).

Anthropologists today claim to be uninterested in grand narratives, and to be more explicitly concerned with local particularities and historically specific manifestations of cultural practices. Very few are prepared to think of cultures and societies simply as structured combinations of elements, and as has often been pointed out, this tendency to confer more agency to 'structures' than to humans is one of the principal features of Lévi-Strauss's structural version of anthropology, making it at the very least quite problematic. Yet LéviStrauss's argument that taxonomy is a characteristic feature of human thought shows the extent to which practices that meaningfully distinguish one human group from another are central to his works

While he identified totemism as one of the important ways in which such classifications were manifested (1962b), many anthropologists in their ethnographies now explore similar taxonomic practices when untangling identity politics of race, ethnicity, religion, indigeneity, gender and sexuality as these emerge in various contexts around the globe, or in their approach to conflicts between groups and their others, endeavouring to discern the shape, force and effect of political violence in its state-based and transnational articulations

Classification and taxonomy continue to be central to anthropological research, whether through a focus on how friction and state involvement reproduce difference or a consideration of how everyday practices reinscribe otherness. Albeit sometimes inadvertently, most of these studies end up restating Lévi-Strauss's claim that, if the social is the very essence of the human, it is the creative possibilities enabled by relational difference that are the very essence of the social. Indeed, as evinced by Race and History (1952a), Lévi-Strauss dismissed the idea that there was any biological basis for 'race', opposed evolutionist arguments proclaiming the superiority of Western civilization, rejected the view that some cultures are outside of history, and suggested that no single civilization can ever itself take credit for its accomplishments since no culture exists in isolation.
Another general trend can be discerned in a significant number of works on colonialism, military bases, embedded anthropologists, humanitarianism and interventionism, or a range of studies whose objects of analysis lie at the nexus where science, politics and markets meet in what is seen as the creeping expansion of neo-liberal logics and their implications for the state as a political formation. This trend reveals an ongoing interest among anthropologists in new forms and contexts of market capitalism, and a deepening concern for the imbrications of political and scientific epistemologies, particularly as they emerge in the multiple, complex and even contradictory orientations of state policies and social actions around issues of public health, the environment and natural resources (Richland 2009).

Each of these trends and concerns undoubtedly engages anxieties expressed by Lévi-Strauss in his distaste for the 'mechanical civilization' of the West. While his first UNESCO text on race and history (1952a) became a classic of antiracism in its critique of Western ethnocentric humanism, in his second UNESCO essay on race and culture (1983: 21-48) he has been considered as coming scandalously close to a racist position, even though he always claimed imperturbably that the two texts expressed the same convictions. He claimed that the civilizing process results in a demographic explosion, leading to the intensification of exchanges which in their turn lead to the destruction of cultural and natural diversity. Overpopulation must indeed lead to the devastation of all natural resources and, quite mechanically, to an increasingly harmful promiscuity that inevitably generates intolerance, since individuals, unable to tolerate it, develop feelings of hatred and hostility towards their fellows, who henceforth seem to them strikingly unlike themselves. Hence, this must be the very origin of xenophobic and racist ways of thinking and acting.

Lévi-Strauss was arguably justified in believing that his two texts on race were expressions of a similar, if evolving, conviction. In spite of an increasing pessimism, he must have developed 'private' and 'public' versions of his beliefs (Stoczkowski 2008). The private version seems fatalist and resigned, seeing humanity as doomed in the face of demographic explosion and Western ethnocentric humanism. Salvation therefore becomes a matter of resigned personal adaptation to the imperfections of the world, taking the form of a Buddhist or stoic detachment from it. The public view is more optimistic and even voluntarist, offering hope that the increasing trend towards globalization and the destruction of diversity will be stemmed by an opposing project of collective salvation in the form of a return to the essential properties of man and society.

In Lévi-Strauss's vision, the anthropologist is seen as the conscience and consciousness of the West, the 'witness' and ambivalent mediator of cultural diversity and cultures radically different from our own, destroyed by the very locality from which he could not have been extricated himself. That is why, 'above all in gloomy times', the task of anthropology must consist in arousing 'a permanent possibility of humanity' that is embedded 'in the ways of thought and life' of non-Western societies. Lévi-Strauss thus urges anthropology to 'extend humanism to the measure of humanity' (1973: 44). Rather than being racist, such a 'generalized' humanism integrates all human cultures, and anthropology becomes the instrument of this 'new' humanism in its redemptive mission (Doja 2008b).

\section{Anthropological futures}

The return to Lévi-Strauss's thermal analysis of history and his provocative distinction between 'historical temperatures' in his model of 'cold' and 'hot' societies (Charbonnier 1961: 37-48) is now being advocated as a heuristic rather than taxonomic distinction between 'cultural eras'. If its continued utility can be argued as a workable methodology for anthropological investiga- 
Moran, M.H. 2010

(forthcoming). Gender, militarism, and peacebuilding: Projects of the post-conflict moment. Annual Review of Anthropology 39:

Nascimento, C.-M. 2008. Exploring hypermedia through the myths. Technoetic Arts, 6(3):269-285.

Petitot, J. 1988. Approche morphodynamique de la formule canonique du mythe. L'Homme, 28(106107): $24-50$

Richland, J.B. 2009. On neoliberalism and other social diseases: The 2008 sociocultural anthropology year in review. American Anthropologist 111(2): 170-176.

Sahlins, M. 2010

Infrastructuralism: Claude Lévi-Strauss in memoriam", Critical Inquiry, 36(3):371385

Santucci, J.-F., De Gentili, E \& Thury-Bouvet, G. 2010. Discrete event modeling and simulation of the mythical thought morphodynamics involved in Claude

Lévi-Strauss structural analysis. In: Blanchard, E.G. \& Allard, D. (eds), Handbook of research on culturally-aware information technology: Perspectives and models. Hershey, N.Y.: Information Science Reference, pp. 152-178

Schneider, D, 1984. A critique of the study of kinship. Ann Arbor, MI: University of Michigan Press.

Scubla, L. 1998. Lire LéviStrauss: Le déploiement d'une intuition. Paris: Odile Jacob.

Sissons, J. 2010. Building a house society: the reorganization of Maori communities around meeting houses. Journal of the Royal Anthropological Institute, 16(2):372-386

Sontag, S. 1990[1963]. The anthropologist as hero. In Against interpretation, pp 69-81. New York: Anchor Books.

Sperber, D. 2008. Claude Lévi-Strauss, a precursor? European Journal of Sociology 49(2): 309-314.

Stoczkowski, W. 2008. Anthropologies rédemptrices: le monde selon Lévi-Strauss. Paris Hermann

Strong, T. 2002. Kinship between Judith Butler and anthropology? A review essay. Ethnos: Journal of Anthropology 67(3): 401 418.

Terray, E. 2010, La vision du monde de Claude LéviStrauss, l'Homme, 1/193: 23-44.

Wagner, R,. 2009. Mathematical variables as indigenous concepts. Internationa Studies in the Philosophy of Science, 23(1):1-18

Wiseman, B. (ed.) 2009. The Cambridge companion to Lévi-Strauss. Cambridge: Cambridge University Press. tion, correspondingly, the constant distinctions between structure and event, or action and agency, can similarly be regarded more as analytical conventions than as conditions of cultural and social reality. This may be all the more important in guarding against academic 'ways of seeing' becoming reified and congealed, for we can move forward to make more of the need for analytical fluidity and theoretical hybridity. One could read this continuous reconsideration and revision as indicative of another example of Fischer's (2009) 'anthropological futures', in which the potential symbiotic 'bricolage' of seemingly contradictory approaches becomes important.

As social and political institutions, events and movements become increasingly complex, Lévi-Strauss's theory can offer critical new perspectives for the analysis of power, politics and social action and, importantly, help to develop political solutions. Indeed, a key advantage of structural analysis is that the categories of analysis, as discussed by Lévi-Strauss, allow for an in-depth analysis of how thoughts can develop at the individual level and be transformed into action on a collective level. This is critical to understanding the underlying motivations of members of political movements, who seek to overcome difficult individual circumstances by transcending negative social and political circumstances, not least through violence.

Actually, a more closely-argued and clearly-defined theoretical framework could be designed using a careful combination of Lévi-Straussian structural analysis, cognitive commitments, borderland epistemology and the politics of practice and agency. Though this is a topic for further examination at another time, I would argue that such an attempt could provide another instance in which our theoretical understanding of the world can be made to progress, in the context of a general revival of the kind of vigorous theoretical debate that tended to disappear from the field in the 1980s.

In particular, a critical understanding of the interplay of ideology and culture as political instruments of hegemony and power, which would be especially suited to revealing a new and unsuspected meaning involved in unified visions of the integration of knowledge, could point toward some neglected but potentially vigorous developments in current social and anthropological theory that may not only present new empirical material and substantive findings, but also generate novel conceptual and theoretical syntheses to open up innovative research avenues.

More than anything else, it can be argued that the new morphodynamic epistemological project of the structural paradigm in current anthropology might go well beyond the general discourse in social science which speaks authoritatively about identity shifting, hybridity, fluidity, liquidity and the like, but nevertheless without any conclusive certainty, nor sufficient precision to distinguish clearly how identity changes occur in the first instance. Social identities may be as ambivalent and fluid as symbols, myths, sensory qualities and arts seemed once to be, before the advent of Lévi-Strauss's theory. For example, it is the parallel between the narrative structure of hypermedia and the structure of mythical narratives described by Lévi-Strauss that has offered a new perspective for the understanding and manipulation of hypermedia logic structures, the resources related to the temporality and spatiality of narratives mobilized to form a coherent whole, and their own alternative means of producing meaning (Nascimento 2008). Hence, to achieve greater precision and rigour in contemporary anthropology too, it may be helpful to consider the very heart of transformational analysis, and acknowledge what the structural approach can offer to critical political and historical approaches.

Our understanding of 'reflexivity' may be strengthened if we consider that perhaps it is not so much a question of ambiguous or paradoxical human conditions, but rather the result of a 'transformational twist' at the crossings of boundary conditions. Arguably, a canonically informed concept of border-crossing and agency may warn against allowing facile ideas such as 'at borders, two sides equal one hybrid', which replace analysis and so neglect the very real power of the dominant majority to advance ideological and political projects.

The theoretical project inspired by the canonical formula can show that structural anthropology is also intimately concerned with processes of social conflict, change, praxis and agency - a neglected but essential aspect of Lévi-Strauss's theory. The generative virtues of the so-called 'double twist' of the canonical transformation in Lévi-Strauss's structural study of myth, which imply two operating conditions internal to canonical formalization (Lévi-Strauss 1958: 252-253), are now being considered and made comprehensible as an anticipated formalization of catastrophe models in new mathematics and morphodynamics (Petitot 1988, Scubla 1998, Maranda 2001). I believe they could reasonably stand for the notions of development and global change as understood in contemporary social science, for the lack of which Lévi-Strauss has been vehemently but unduly criticised. That a transformational twist of this kind can also account for the processes of social conflict, change, praxis and agency might seem at first sight as an unusual if not provocative statement.

Yet, the very idea of canonical relation requires a third operating condition, external to canonical formalization, which in the study of myth is expressed as the necessity of the crossing of a spatiotemporal boundary, defined in territorial, ecological, linguistic, cultural, social or whatever terms, but which is always a boundary condition. Lévi-Strauss claims that the catastrophist operation that requires a boundary condition of this kind shows that a series of variations inherent in the myths of a given people cannot be fully understood without going through myths belonging to another people, which are in a relation of inverse transformation with the former. Ultimately, as I have shown elsewhere, the requirement of a boundary condition in canonical formalization can anticipate the politics of an ideological agency and discursive practice (Doja 2009), for the lack of which structural analysis has been undeservedly dismissed.

Fundamentally, although the majority of commentators, be they admirers or critics, retained from the structural analysis of myth only its capacity to disclose stable, common and probably universal frameworks, Lévi-Strauss preferred to look for rules that would ideally make it possible to generate, starting from an unspecified myth of reference, the finite or infinite whole of all other real or possible myths. If we agree with this epistemological insight as a final innovative direction, I argue that we may establish a more sophisticated approach, following structural procedures of transformational analysis and formalization.

It may not hitherto have been expressed so directly, but this means that we may be correct in asserting that we can in theory deduce from an empirical situation of identity construction, social change, ethnic identification or social conflict, transcribed in the canonical way, the possibly hidden reality of an external boundary, borderland existence or border-crossing movement. This reality would reveal itself elsewhere (Doja 2009) in the form of an ideologically or politically instrumental agency.

It will necessarily be organized around a specific identity element or social hierarchy associated with the value of one identity moment, human agency and social action, but having inverse propositional characteristics to that moment, course of action and agency. And vice versa: new identity constructions and social changes can be anticipated as a result of the mediating logical operation of a boundary condition, and we can set off in their search and their appreciation. 